\title{
A Comparative Discussion of the Judicial Disqualification of Directors under the South African Companies Act
}

\author{
Rehana Cassim* (1) \\ University of South Africa \\ cassir@unisa.ac.za
}

\begin{abstract}
Section 162 of the South African Companies Act 71 of 2008 empowers courts to declare directors delinquent and hence to disqualify them from office. This article compares the judicial disqualification of directors under this section with the equivalent provisions in the United Kingdom, Australia and the United States of America, which have all influenced the South African act. The article compares the classes of persons who have locus standi to apply to court to disqualify a director from holding office, as well as the grounds for the judicial disqualification of a director, the duration of the disqualification, the application of a prescription period and the discretion conferred on courts to disqualify directors from office. It contends that, in empowering courts to disqualify directors from holding office, section 162 of the South African Companies Act goes too far in certain respects.
\end{abstract}

\section{Keywords}

Judicial disqualification of directors, delinquent directors, substantial misconduct of directors, judicial interference in internal affairs of a company

\section{INTRODUCTION}

A significant innovation in the Companies Act 71 of 2008 (the SA Companies Act), which came into force on 1 May 2011, is section 162, which empowers a court to make an order declaring a director to be delinquent on various grounds. The effect of a delinquency order is that the director in question is disqualified and prohibited from holding office as a director of any company. ${ }^{1}$ There is no need for a court specifically to order the removal of a delinquent person from office because of the "automatic inherent effect of such a

* BA (cum laude), LLB (cum laude), LLM (cum laude) (Witwatersrand), LLD (Unisa). Associate professor, Department of Mercantile Law, School of Law, University of South Africa; attorney; notary public of the High Court of South Africa. This article is based on sections of the author's doctoral thesis.

1 SA Companies Act, sec 69(8)(a). See also Rabinowitz v Van Graan and Others 2013 (5) SA 315 (GSJ), para 20; Grancy Property Limited v Gihwala 2014 JDR 1292 (WCC), para 159; Lewis Group Limited v Woollam 2017 (2) SA 547 (WCC), para 5. 
declaration".2 A delinquency order may subsist for the lifetime of the director or for seven years or longer, as determined by the court. ${ }^{3}$

The removal of a director by a court under section 162 must be distinguished from the internal removal of a director by shareholders under section 71(1) of the SA Companies Act by means of an ordinary resolution, or the removal of a director by the board of directors under section 71(3) by means of a board resolution. ${ }^{4}$ The disqualification of a director by a court under section 162 requires an application to court, by a party with the necessary standing, for an order to declare a director delinquent. Should a director be removed from office by the shareholders or by the board under section 71 , his or her removal would be specific to that particular company, but a disqualification by a court under section 162 would disqualify the director from participating in the management of any company. ${ }^{5} \mathrm{~A}$ further distinction must be made between the automatic grounds for disqualification, as set out in section 69 of the act, which do not require an order of court, ${ }^{6}$ and applications to court under section 162 to disqualify directors from office. The focus of this article is on the disqualification of directors following a court application under section 162 of the SA Companies Act, ${ }^{7}$ and not on the internal removal of directors by the shareholders or the board, nor on the automatic disqualification of directors.

It is noteworthy that section 5(1) of the SA Companies Act requires the act to be interpreted and applied in a manner that gives effect to its purposes in section 7. One particular purpose, contained in section $7(\mathrm{i})$, is to balance the rights and obligations of shareholders and directors within companies. Other relevant purposes are to: promote the development of the South African economy by encouraging entrepreneurship and enterprise efficiency; ${ }^{8}$ encourage the efficient and responsible management of companies; ${ }^{9}$ and

2 Kukama $v$ Lobelo 2012 JDR 0062 (GSJ), para 22; Msimang NO and Another $v$ Katuliiba and Others [2013] 1 All SA 580 (GSJ), para 32.

3 SA Companies Act, sec 162(6).

4 Sec 71(3) permits the board of directors to remove a director from office in certain defined instances.

$5 \mathrm{JJ}$ du Plessis and JN de Koker "Analyses, perspectives and jurisdictional overview” in JJ du Plessis and JN de Koker (eds) Disqualification of Company Directors: A Comparative Analysis of the Law in the UK, Australia, South Africa, the US and Germany (2007, Routledge) 1 at 5.

6 If a director falls under any of the grounds of ineligibility or disqualification set out in sec 69 during his or her term of office, he or she would automatically cease to be entitled to continue to act as a company director.

7 It is noteworthy that, under sec 162(7) of the SA Companies Act, a court may also make an order placing a person under probation. The maximum period for which a probation order subsists is five years. A person under a probation order may still act as a director, but only to the extent permitted by the order. Since a probation order does not necessarily disqualify a person from acting as a director, this article is confined to an analysis of delinquency orders.

8 SA Companies Act, sec 7(b)(i).

9 Id, sec $7(\mathrm{j})$. 
provide a predictable and effective environment for the efficient regulation of companies. ${ }^{10}$ As stated in Cape Empowerment Trust Ltd $v$ Druker, ${ }^{11}$ effect must be given to these purposes when interpreting and applying section 162 .

Section 5(2) of the SA Companies Act provides that, to the extent appropriate, a court interpreting or applying the act may consider foreign law. In Nedbank Ltd $v$ Bestvest 153 (Pty) Ltd; Essa $v$ Bestvest 153 (Pty) Ltd, ${ }^{12}$ the High Court observed that company law in South Africa has for many decades tracked the English system and has taken its lead from the relevant English Companies Act and jurisprudence, but that section 5(2) now encourages South African courts to look further afield in interpreting the act, and to have regard in appropriate circumstances to other corporate law jurisdictions, be they American, European, Asian or African. Notably, courts in the United Kingdom (UK), Australia and the United States of America (USA) are also empowered to disqualify directors from holding office. The corporate legislation of these jurisdictions has strongly influenced the SA Companies Act. Consequently, and as buttressed by section 5(2), this article compares the judicial disqualification of directors from office under section 162 of the SA Companies Act with the equivalent provisions in the UK, Australia and the USA. The relevant provisions of the Company Directors Disqualification Act 1986 (the CDDA), which regulates the disqualification of directors in the UK, are examined for the reason that South African company law is historically based on the English company law system. Relevant provisions of the Australian Corporations Act of 2001 (Australian Corporations Act), which is also historically based on UK company law, are also reviewed in order to ascertain whether any useful and relevant guidelines may be gleaned. ${ }^{13}$ It is also beneficial and informative to investigate the scope of the judicial power to remove directors from office under the Revised Model Business Corporation Act 1984 of the USA (MBCA) and under the corporate legislation of certain US states. ${ }^{14}$

$10 \mathrm{Id}$, sec $7(1)$.

112013 JDR 1360 (WCC), para 85.

122012 (5) SA 497 (WCC), para 26.

13 While company law in Australia is historically based on UK company law, present-day company law in Australia under the Australian Corporations Act is less dependent on UK company law; see further CM Bruner Corporate Governance in the Common-Law World: The Political Foundations of Shareholder Power (2013, Cambridge University Press) at 66.

14 The USA has a federal system where federal law is enacted by the US Congress while state law is enacted by individual state legislatures. Each state has its own legal system and judiciary, which are separate from the federal system. Generally, state law provides for corporate law matters, which are regulated by the 50 states. This article deals with the judicial removal of directors under state, not federal, law. For a discussion of the judicial removal of a director of a public company on application by the Securities and Exchange Commission under the Securities Act 1933, the Securities Exchange Act 1934 and the Sarbanes-Oxley Act 2002, see HM Farhan and JN de Koker "The United States" in du Plessis and de Koker (eds) Disqualification of Company Directors, above at note 5, 155 at 163-65. 
The locus standi [capacity to bring legal action] to apply to court to disqualify a director from holding office is compared, as are the grounds for the judicial disqualification of a director, the duration of the removal, the prescription period to initiate court proceedings and the discretion conferred on courts to disqualify directors from holding office. The article contends that section 162 of the SA Companies Act is, in certain respects, wider, stricter and more far-reaching than the equivalent provisions in the UK, Australia and the USA, and that it goes too far in certain respects in empowering courts to disqualify directors from office. Drawing on the equivalent provisions in the UK, Australia and the USA, the article recommends modifications to section 162 with a view to improving the regulation of the judicial disqualification of directors under South African law, and to serve the statutory purposes of the act better.

\section{PURPOSE OF SECTION 162}

The innovation in section 162 of the SA Companies Act lies in the introduction of a new civil remedy for those harmed by the conduct of delinquent directors. ${ }^{15}$ This section does not invoke criminal liability. The assessment of whether a director is delinquent will therefore be determined on a civil standard of proof and on the balance of probabilities. Section 162 has an underlying protective purpose: it is directed at protecting companies and corporate stakeholders from directors who have proven themselves unable to manage the business of the company or have failed in, or are in neglect of, their duties as directors. ${ }^{16}$ Orders disqualifying directors from acting as such are designed to maintain high corporate standards and to prevent unlawful and fraudulent behaviour. ${ }^{17}$

To the extent that section 162 does not impose a criminal sanction, the provision is clearly not a penal one. It is, however, submitted that the proceedings do nonetheless embody a punitive element. As reaffirmed by BrowneWilkinson V-C in Re Lo-Line Electric Motors Ltd, ${ }^{18}$ if the court's power to disqualify a director is exercised, there is inevitably substantial and significant interference with the individual's entrepreneurial freedom. It follows that the individual's rights must be fully protected. ${ }^{19}$ In approving this approach, in Re Crestjoy Products Ltd the Chancery Division observed that, when a court is faced with a mandatory disqualification period once the facts are proved, the matter becomes somewhat more penal. ${ }^{20} \mathrm{~A}$ further punitive effect of a

15 Grancy $v$ Gihwala, above at note 1, para 155.

16 Msimang $v$ Katuliiba, above at note 2, para 29; Gihwala and Others $v$ Grancy Property Limited and Others 2017 (2) SA 337 (SCA), para 14; Lewis $v$ Woollam, above at note 1, para 40.

17 Rich v Australian Securities and Investments Commission [2004] 220 CLR 129, para 49.

18 [1988] 2 All ER 692 at 696.

19 Ibid. See further Re Gibson Davies Ltd [1995] BCC 11 at 14

201990 BCC 23 at 26. 
declaration of delinquency is that it carries a stigma. ${ }^{21}$ The reputational damage caused by a delinquency order is extensive and is likely to endure for a long time. In Secretary of State for Trade and Industry $v$ Collins and Others, the UK Court of Appeal acknowledged the penal elements involved in the disqualification of a director. ${ }^{22}$ Several Australian courts have also recognized that disqualification orders are not purely or entirely protective and that they do include a penal element. ${ }^{23}$

\section{INDIRECT REMOVAL POWER}

The power conferred on a court to remove a director from office under section 162 of the SA Companies Act is indirect, not direct. This is because a court is empowered to declare a director delinquent, which has the effect of disqualifying the person from being a director. As the High Court declared in Kukama $v$ Lobelo $^{24}$ and Msimang $v$ Katuliiba, ${ }^{25}$ there is no need for a court specifically to order the removal of a delinquent person from office because of the "automatic inherent effect of such a declaration".

Thus, under South African company law, one may not apply directly to a court to remove a director from office; instead, this must be done in the context of a court application to declare a director delinquent. This approach is modelled on UK and Australian company legislation. In the UK, a disqualification order under the CDDA has the effect that a person may not, without leave of the court, be a director of the company or be concerned in any way or take part in the promotion, formation or management of a company. ${ }^{26}$ Likewise, sections 206C, 206D, 206E and 206EEA of the Australian Corporations Act (titled "Court power of disqualification") confer on courts the power to disqualify directors from managing corporations and hence indirectly remove them from office.

In contrast, section 8.09(a) of the MBCA (titled "Removal of directors by judicial proceeding") confers on courts the direct power to remove directors from office, on application by or in the name of the corporation. Most US states have statutory procedures for the judicial removal of directors and also confer on courts a direct power to remove directors from office. ${ }^{27}$

21 Re Westminster Property Management Ltd Official Receiver v Stern 2001 BCC 121, para 36.

22 [2000] BCC 998 at 1007.

23 See for instance: Rich $v$ ASIC, above at note 17, paras 32, 35 and 50-52; Australian Securities and Investments Commission v Beekink [2007] FCAFC 7, paras 80-91; Australian Securities and Investments Commission v Axis International Management Pty Ltd (No 6) [2011] FCA 811 (2011), para 9; Gilfillan and Others v Australian Securities and Investments Commission [2012] NSWCA 370, paras $180-85$.

24 Above at note 2, para 22.

25 Above at note 2, para 32.

26 CDDA, sec 1.

27 See for example: Arizona Revised Statutes, sec 10-809(A); California Corporations Code, sec 304; Connecticut General Statutes, sec 33-743(a); Pennsylvania Business Corporation Law, sec 1726(c); and Washington Business Corporation Act, sec 23B.08.090(1). 


\section{LOCUS STANDI TO APPLY TO COURT TO REMOVE A DIRECTOR}

Section 162 of the SA Companies Act gives a very wide range of persons locus standi to apply to court to declare a director delinquent: a company; a shareholder; a director; the company secretary; a prescribed officer of a company; a registered trade union that represents employees of the company or another employee representative; the Companies and Intellectual Property Commission (CIPC) (South Africa's corporate regulator); the Takeover Regulation Panel; and any organ of state responsible for the administration of legislation. ${ }^{28}$ The equivalent provisions in the CDDA, the Australian Corporations Act, the MBCA and the corporate legislation of relevant US states do not confer such locus standi on the company secretary, trade union or employee representative, whose position is unique to South African corporate law. There is much potential for a trade union or another employee representative to put directors under pressure by exercising or threatening to exercise such rights. ${ }^{29}$ Section 162 confers legal standing on shareholders and other stakeholders, even though the directors' misconduct may not infringe their rights and irrespective of whether the directors' duties are owed directly to them. ${ }^{30}$ Even a single shareholder or a single director may bring an application under section 162 to declare a director delinquent, thus conferring considerable power on that person.

The CDDA confers locus standi on the secretary of state (or the official receiver acting under the direction of the secretary of state) to apply to court for an order disqualifying unfit directors. ${ }^{31}$ Under section 9A(10) of the CDDA, the Competition and Markets Authority and a "specified regulator" have standing to apply to court for a disqualification order in the case of competition infringements. Under section $9 \mathrm{E}(2)$, "specified regulators" are the Office of Communications, the Gas and Electricity Markets Authority, the Water Services Regulation Authority, the Office of Rail and Road, the Civil Aviation Authority, Monitor, the Payment Systems Regulator and the Financial Conduct Authority. An application for a disqualification order for general misconduct in connection with companies may be made by the secretary of state, the official receiver of a company being wound-up, the liquidator, or any past or present members or creditors of a company or overseas company in relation to which the person concerned has committed an offence or other default. ${ }^{32}$ Under section $5 \mathrm{~A}$ of the CDDA, the secretary of state may also apply to court for a disqualification order against a person who has

28 SA Companies Act, secs 162(2), (3) and (4).

$29 \mathrm{~J}$ du Plessis and P Delport “'Delinquent directors' and 'directors under probation': A unique South African approach regarding disqualification of company directors" (2017) 134/2 South African Law Journal 274 at 277.

30 Id at 293.

31 CDDA, secs 6, 7(1)(b) and 8.

32 Id, sec 16(2). 
been convicted of a relevant foreign offence. ${ }^{33}$ When a court makes a declaration under section 213 (fraudulent trading) or section 214 (wrongful trading) of the Insolvency Act 1986 to the effect that a person is liable to make a contribution to a company's assets, then (regardless of who applied for the declaration) the court may, if it thinks fit, also make a disqualification order against that person. ${ }^{34}$

In certain respects, the persons who have been conferred locus standi under the CDDA are more extensive than those in section 162 of the SA Companies Act. For instance, section 162 does not permit a liquidator, creditor or specified regulator to apply for a court order disqualifying a director. In the case of a disqualification for fraudulent trading or wrongful trading under section $10(1)$ of the CDDA it appears, in a sweeping provision, that "any person" may apply to court for a disqualification order against the miscreant director. These words indicate that very wide standing has been conferred under this particular ground for disqualification. In other respects, however, section 162 of the SA Companies Act empowers a wider group of persons to apply to court to disqualify a director from holding office compared to the CDDA. For instance, the CDDA does not explicitly empower a director to apply to court to disqualify another director from office. A director may nevertheless have locus standi under section 10(1) of the CDDA (relying on the words "any person"), but this would be limited to instances of fraudulent and wrongful trading. While a shareholder has been conferred locus standi under section 162(2) of the SA Companies Act, under the CDDA a shareholder may only in limited instances institute an application to disqualify a director. ${ }^{35}$

The contrast between the persons who have locus standi to apply to court to disqualify a director and hence remove him or her from office under the Australian Corporations Act compared to the SA Companies Act is much more striking. The Australian Securities and Investment Commission (ASIC), Australia's corporate regulator, is the only body that may apply to court to disqualify a director from holding office. ${ }^{36}$ Neither a shareholder nor a director has such locus standi. A limitation of this approach is that less serious contraventions might by overlooked by ASIC since the pursuit of such offences might not have as much of a deterrent effect as the pursuit of more serious

33 This is an offence committed outside Great Britain in connection with the "promotion, formation, management, liquidation or striking-off of a company (or any similar procedure)" or "a person being an administrative receiver of a company (or holding a similar position)" and "which corresponds to an indictable offence under the law of England and Wales" or Scotland: CDDA, sec $5 \mathrm{~A}(3)$.

34 Id, sec 10(1).

35 These instances are: disqualification on conviction of an indictable offence in connection with the promotion, formation, management, liquidation or striking-off of a company; disqualification for persistent breaches of company legislation; and disqualification for fraud in the winding-up of a company: id, secs 2, 3, 4 and 16(2).

Australian Corporations Act, part 2D.6. 
contraventions that would probably result in long periods of disqualification for miscreant directors. ${ }^{37}$

As is the position under the Australian Corporations Act, under the MBCA and the corporate legislation of various relevant US states, a single shareholder and a single director do not enjoy locus standi to apply to court to remove a director. Under section 8.09(a) of the MBCA and section 225(c) of the Delaware General Corporation Law (the DGCL), ${ }^{38}$ the board of directors or a shareholder suing derivatively in the name of the company has locus standi to apply to court to "remove a director from office". The corporate legislation of several US states requires shareholders holding at least ten per cent of the outstanding shares to institute a court application to remove a director from office. ${ }^{39}$ South Carolina requires five per cent of the outstanding shares to be held by a shareholder in order to bring an action to remove a director from office. ${ }^{40}$ Only one US state, Pennsylvania, permits a single shareholder to institute an action to remove a director from office: section 1726(d) of the Pennsylvania Business Corporation Law provides that "any" shareholder or director may apply to court to remove a director from office. The company must nevertheless be a party to the application and the shareholder must comply with the requirements relating to derivative actions.

In the controversial South African case of Lewis Group Limited $v$ Woollam (Lewis $v$ Woollam), ${ }^{41}$ Woollam, a minority shareholder of Lewis Group Limited, instituted proceedings to declare delinquent the company's chief executive officer, chief financial officer, chairperson of the board and chairperson of the audit and risk committee. Lewis Group Limited is a public company listed on the Johannesburg Stock Exchange, with over 700 retail outlets in South Africa. Woollam instituted the proceedings to declare the directors delinquent using the derivative action remedy. ${ }^{42}$ The High Court held that a shareholder may not use the derivative action to declare a director delinquent,

37 T Blackie and JJ du Plessis "Australia" in du Plessis and de Koker (eds) Disqualification of Company Directors, above at note 5, 69 at 101.

38 Delaware Code, title 8, chap 1.

39 See, for example: California Corporations Code, sec 304; Washington Business Corporation Act, sec 23B.08.090(1); New York Business Corporation Law, sec 706(d); and Rhode Island Business Corporation Act, sec 7-1.2-805(d). Under the latter two statutes, the attorney general may also apply to court to remove a director from office.

40 South Carolina Code of Laws, sec 33-8-109(a).

41 Above at note 1.

42 A derivative action relates to proceedings instituted by persons given standing to litigate in their own names for and behalf of a corporation in respect of wrongs done to the corporation (see SA Companies Act, sec 165 and Lewis $v$ Woollam, id, para 27). A derivative action is brought by an applicant on behalf of a company in order to protect the company's legal interests. Where a wrong is done to the company, the "proper plaintiff" is the company itself and not the shareholders; see Foss $v$ Harbottle (1983) 2 Hare 461, 67 ER 189 and MF Cassim The New Derivative Action under the Companies Act: Guidelines for Judicial Discretion (2016, Juta) at 5-8. Therefore, the derivative action is an exception to the "proper plaintiff" rule. 
and that this action must be brought personally by a shareholder, in his or her own name. After investigating the preliminary procedures under section 165 of the SA Companies Act with regard to derivative proceedings, the court held that these procedures are not well suited to derivative proceedings by shareholders to declare directors delinquent. ${ }^{43}$ The court accordingly ruled that "it is not within the scheme" of the SA Companies Act that shareholders should ordinarily seek to proceed derivatively to obtain a delinquency order under section $162 .{ }^{44}$

In sharp contrast, both the MBCA and the DGCL make explicit provision for derivative action proceedings to be instituted by a shareholder to remove a director from office. Under section 8.09(a) of the MBCA, a court may "remove a director from office" in proceedings commenced "by or in the right of the corporation". The proceedings must be brought by the board of directors, or by a shareholder, who must sue derivatively. Section 8.09(b) of the MBCA states that a shareholder proceeding on behalf of the corporation under section 8.09(a) must comply with the requirements of subchapter 7D of the MBCA, dealing with derivative actions. Likewise, section 225(c) of the DGCL states that judicial removal proceedings must be instituted "upon application by the corporation, or derivatively in the right of the corporation by any stockholder". Some other US states that also require judicial removal proceedings of a director to be commenced derivatively in the name of the company by the shareholders are Connecticut, ${ }^{45}$ the District of Columbia, ${ }^{46}$ Idaho, ${ }^{47}$ South Dakota ${ }^{48}$ and Pennsylvania. ${ }^{49}$ Comparatively, section 162(2) of the SA Companies Act is wider than the MBCA, the DGCL and the corporate legislation of several relevant US states in that it not only permits a single shareholder to commence judicial disqualification proceedings under section 162 but, according to Lewis $v$ Woollam, ${ }^{50}$ such proceedings may not be commenced derivatively by the shareholder but must be commenced in the shareholder's own name.

In light of the extensive range of persons who are empowered to apply to court to disqualify a director from holding office under section 162(2) of the SA Companies Act, it becomes important to guard against abuse of the section. This is because frivolous and vexatious applications may be lodged by persons with locus standi. Such applications may result in harm to the company and to the reputation of its directors. This is especially important with regard to a

43 Lewis $v$ Woollam, id, paras 45-49.

44 Id, para 49. For a critique of this judgment, see R Cassim "The launching of delinquency proceedings under the Companies Act 71 of 2008 by means of the derivative action: Lewis Group Limited v Woollam 2017 (2) SA 547 (WCC)" (2017) 38/3 Obiter 673.

45 Connecticut General Statutes, secs 33-743(a) and (b).

46 District of Columbia Code, sec 29-306.09(a).

47 Idaho Code, sec 30-29-809(2).

48 South Dakota Business Corporation Act, sec 47-1A-809.

49 Pennsylvania Business Corporation Law, sec 1726(c).

50 Above at note 1. 
listed public company, where the value of the company's shares could easily be affected by the mere lodging of an application under section 162 .

This is precisely what occurred in Lewis $v$ Woollam. Lewis Group Limited argued that, in instituting proceedings to have four directors of the company declared delinquent, Woollam had not acted in good faith and that his application was vexatious. The company contended that Woollam was involved in market manipulation, namely short-selling activities, and that his conduct in instituting delinquency proceedings was aimed at driving down the company's share price in order to benefit his activities. ${ }^{51}$ The negative publicity as a result of the delinquency proceedings did in fact have an adverse effect on the company's share price. ${ }^{52}$ While the court noted that Woollam had failed to disclose his short-selling activities and that this had raised an ethical question, ${ }^{53}$ it did not decide whether Woollam had acted in bad faith as the matter had already been referred by the company to the Financial Sector Conduct Authority for investigation. Due to insufficient evidence, this body subsequently cleared Woollam of any wrongdoing. ${ }^{54}$

This case illustrates the extent of the power conferred on a single shareholder to institute proceedings to declare a director delinquent. Section 162 of the SA Companies Act does not contain safeguards against vexatious or frivolous applications. It is submitted that, if a shareholder were to institute proceedings derivatively to declare a director delinquent, this would have the advantage of expeditiously curbing any abuse of section 162, since a court would be able to screen out at a preliminary stage legal proceedings instituted with an ulterior motive. The damage done to Lewis Group Limited's share price and to the reputation of the directors could have been more extensive had the application been instituted by Woollam personally, and had the directors been involved in a protracted legal battle in terms of section 162 .

\section{THE GROUNDS FOR THE JUDICIAL DISQUALIFICATION OF A DIRECTOR}

Section 162(5) of the SA Companies Act lists the specific grounds on which a person with locus standi may rely to apply to court to declare a director

51 Id, para 86.

52 Ibid.

53 Id, para 87.

54 "Report by the Directorate of Market Abuse" (Financial Services Board press release, 28 September 2016), available at: <http://www.fsca.co.za/News\%20Documents/2016-09$28 \% 20(2)$.pdf> (last accessed 30 September 2020); C Smith "Consumer watchdog cleared of Lewis allegations" (30 September 2016) fin24, available at: <http://www.fin24.com/ Companies/Retail/consumer-watchdog-cleared-of-lewis-allegations-20160930> (last accessed 30 September 2020); S Cassidy "Woollam shrugs off 'dirty tricks and lies' in Lewis fight" (30 September 2016) IOL, available at: <http://www.iol.co.za/business-report/companies/ woollam-shrugs-off-dirty-tricks-and-lies-in-lewis-fight-2074840> (last accessed 30 September 2020). 
delinquent. These grounds constitute a substantive abuse of office and such conduct evinces a lack of genuine concern for the company's prosperity. ${ }^{55}$ For a person to succeed in obtaining a declaration of delinquency, very serious misconduct must be demonstrated by the director concerned. ${ }^{56}$ Establishing so-called "ordinary" negligence, poor business decision-making or misguided reliance on incorrect professional advice is insufficient. ${ }^{57}$ Likewise, in Re Lo-Line Electric Motors $\mathrm{Ltd}^{58}$ the court found that ordinary commercial misjudgment is not in itself sufficient to justify disqualification and that the conduct complained of must display a lack of commercial probity.

Under section 162(5), a court must grant an order declaring a director to be delinquent if the person: (i) consented to serve as a director, or acted in the capacity of a director, while ineligible or disqualified to be a director; (ii) while under an order of probation, acted as a director in a manner that contravened that order; (iii) while a director, grossly abused the position of a director; (iv) while a director, took personal advantage of information or an opportunity, or intentionally or by gross negligence inflicted harm upon the company or its subsidiary; (v) while a director, acted in a manner that amounted to gross negligence, wilful misconduct or breach of trust, or in a manner contemplated in sections 77(3)(a), (b) or (c) of the SA Companies Act (unauthorized acts, reckless trading or fraud); (vi) has repeatedly been subject to a compliance notice or similar enforcement mechanism, for substantially similar conduct, under any legislation; (vii) has at least twice been personally convicted of an offence or subjected to an administrative fine or penalty under any legislation; or (viii) within a period of five years, was a director of one or more companies or controlled or participated in the control of a juristic person, irrespective of whether concurrently, sequentially or at unrelated times, that was convicted of an offence or subjected to an administrative fine or similar penalty under any legislation. ${ }^{59}$

55 Grancy $v$ Gihwala, above at note 1, paras 156 and 176; Westerhuis $v$ Whittaker 2018 JDR 0825 (WCC), para 38.

56 Lewis $v$ Woollam, above at note 1 , para 18.

57 Ibid.

58 Above at note 18 at 696.

59 Only the CIPC, the Takeover Regulation Panel and an organ of state may rely on the grounds listed in (vi), (vii) and (viii) above: SA Companies Act, secs 162(3)(b)(i) and 162 (4)(b). For case examples of the application of the grounds of delinquency, see: Kukama $v$ Lobelo, above at note 2; Lobelo v Kukama 2013 JDR 1434 (GSJ); Msimang v Katuliiba, above at note 2; Rabinowitz $v$ Van Graan, above at note 1; Cape Empowerment $v$ Druker, above at note 11; Demetriades and Another $v$ Tollie and Others (1995/2014) [2015] ZANCHC 17 (18 September 2015); Gihwala $v$ Grancy, above at note 16; Lewis $v$ Woollam, above at note 1; and Companies and Intellectual Property Commission $v$ Cresswell and Others (21092/2015) [2017] ZAWCHC 38 (27 March 2017). For discussion of the grounds of delinquency, see further: R Cassim "Governance and the board of directors" in FHI Cassim (ed) Contemporary Company Law (2nd ed, 2012, Juta) 400 at 436-37; and R Cassim The Removal of Directors and Delinquency Orders under the South African Companies Act (2020, Juta) at 257-75. 
In some respects, the grounds to declare a director delinquent and hence to disqualify him or her from holding office are wider and more far-reaching under section 162 of the SA Companies Act, compared to the equivalent provisions in the UK, Australia and the USA, but in other respects they are narrower. For instance, under section 162(5)(c)(iii) of the SA Companies Act, a director may be judicially disqualified from office if he or she intentionally or by gross negligence inflicted harm on the company. Section 8.09(a) of the MBCA and the corporate legislation of some US states contain an equivalent ground for the judicial disqualification of directors, under which a court may remove a director from office if the director had "intentionally inflicted harm on the corporation". ${ }^{60}$ The threshold of misconduct is, however, set higher in the MBCA and the legislation of these US states in that, unlike section 162(5)(c)(iii), gross negligence does not suffice for a court to remove a director from office. Moreover, under these US provisions it must be shown that the director inflicted harm upon the company itself, while section 162(5)(c)(iii) extends this ground to the infliction of harm on a subsidiary of the company.

Under section 8.09(a) of the MBCA and the corporate legislation of some US states, ${ }^{61}$ for a director to be judicially removed from office there must have been some fraudulent conduct by him or her with respect to the company or its shareholders. This ground is again narrower than the equivalent ground in section 162(5)(c)(iv)(bb) of the SA Companies Act. Under the latter provision, read with section $77(3)$ (c) of the SA Companies Act, for a director to be judicially disqualified from office, the fraudulent conduct in question may extend not only to a shareholder of the company, but also to a creditor or employee of the company. Even if the fraudulent conduct does not so extend, it would nevertheless suffice as long as the conduct had some fraudulent purpose.

Under section 162(5)(c)(i) of the SA Companies Act, a director may be declared delinquent if he or she has grossly abused the position of director. The inclusion of the ground of "gross abuse of the position of director" appears to have been influenced by the corresponding section 8.09(a) of the MBCA. ${ }^{62}$ Other US states that have adopted this ground include Connecticut, ${ }^{63}$ the District of Columbia ${ }^{64}$ and South Dakota. ${ }^{65}$ However, section 162(5) of the SA Companies Act goes further than the equivalent provision in the legislation of some US states. For instance, section 8.35(b) of the Business Corporation Act of 1983 of Illinois requires the gross abuse of the position of

60 See, for example: Connecticut General Statutes, sec 33-743(a); District of Columbia Code, sec 29-306.09(a)(1); and South Dakota Business Corporation Act, sec 47-1A-809.

61 See, for example: Connecticut General Statutes, sec 33-743(a); Washington Business Corporation Act, sec 23B.08.090(1); and California Corporations Code, sec 304.

62 The MBCA, sec 8.09(a) states that a court may remove a director from office in proceedings commenced by or in the name of the company if the court finds that the director "grossly abused the position of director".

63 Connecticut General Statutes, sec 33-743(a).

64 District of Columbia Code, sec 29-306.09(a)(1).

65 South Dakota Business Corporation Act, sec 47-1A-809. 
director to have been "to the detriment of the corporation". In contrast, under section 162(5) of the SA Companies Act it is irrelevant whether the director's gross abuse was to the detriment of the company.

The CDDA provides for a variety of grounds on which a court may make a disqualification order, ${ }^{66}$ including: committing an indictable offence in connection with the promotion, formation, management, liquidation or striking off of a company with the receivership of a company's property or through being an administrative receiver of a company; ${ }^{67}$ persistent breaches of company legislation; ${ }^{68}$ fraud in the course of the winding-up of a company; ${ }^{69}$ disqualification on summary conviction; ${ }^{70}$ disqualification for relevant foreign offences; ${ }^{71}$ specific breaches of competition law; ${ }^{72}$ fraudulent and wrongful trading; ${ }^{73}$ and conduct that makes the director unfit to be concerned in the management of the company. ${ }^{74}$ In contrast section 162(5) of the SA Companies Act does not list all of these grounds of disqualification as a basis to declare a director delinquent. For instance, no provision is made for a breach of competition law or a conviction of a foreign offence. In this respect, section 162(5) of the SA Companies Act is narrower than the CDDA.

In practice, most disqualification orders in the UK are made under section 6 of the CDDA. ${ }^{75}$ Under this provision a court must make a disqualification order against a person if it is satisfied that he is or has been a director of a company that has at any time become insolvent, whether while he was a director or subsequently, and that his conduct as a director of that company makes him unfit to be concerned in the management of a company. An additional much wider ground under which a director may be declared to be "unfit" under the CDDA is contained in section 8(1), under which the secretary of state may apply to court for a disqualification order against a person who is or has been a director of a company if it appears to him that it is expedient in the public interest that such an order should be made. Unlike section 6 of the CDDA, a disqualification order on the ground of unfitness under

66 Instead of applying to court for a disqualification order, in certain circumstances the secretary of state may accept a disqualification undertaking from a director if it is expedient to do so in the public interest: CDDA, sec 1A. A disqualification undertaking has the same effect as a disqualification order made by a court after a court hearing.

67 Id, sec 2.

68 Id, sec 3.

69 Id, sec 4.

70 Id, sec 5.

71 Id, sec $5 \mathrm{~A}$.

72 Id, sec $9 \mathrm{~A}$.

73 Id, sec 10.

74 Id, secs 6 and 8.

75 A Belcher "What makes a director fit: An analysis of the workings of section 17 of the Company Directors Disqualification Act 1986” (2012) 16 The Edinburgh Law Review 386 at 388; PL Davies and S Worthington Gower Principles of Modern Company Law (10th ed, 2016, Sweet \& Maxwell) at 249; B Hannigan Company Law (4th ed, 2016, Oxford University Press) at 175. 
section 8 of the CDDA applies whether or not the company is insolvent. Schedule 1 of the CDDA sets out a wide range of factors that a court must take into account in determining whether the director's conduct makes him or her unfit to be concerned in the management of a company. These factors are: the extent to which the person was responsible for the causes of any material contravention by a company or overseas company of any applicable legislative or other requirement; the extent to which the person was responsible for the causes of a company or overseas company becoming insolvent; the frequency of such conduct; and the nature and extent of any loss or harm caused, or potential loss or harm that could have been caused. ${ }^{76}$ These factors are however not exhaustive and a court is entitled to take into account any misconduct that may show unfitness. ${ }^{77}$ This considerably broadens the grounds of disqualification of a director under the CDDA compared to the grounds of delinquency under section 162 of the SA Companies Act. ${ }^{78}$

In certain respects, section 162 of the SA Companies Act is broader than sections 206C, 206D, 206E and 206EEA of the Australian Corporations Act, while in other respects it is narrower. For instance, under section 206C of the Australian Corporations Act a court may disqualify a person from managing corporations for a period that the court considers appropriate following a declaration under section 1317E that a person has contravened a relevant civil penalty provision. Civil penalty provisions relate to, inter alia: the fiduciary duties of company directors, such as the duty to exercise powers and discharge duties in good faith in the best interests of the corporation and for a proper purpose; and the duty not to improperly use one's position as a director or information obtained in the capacity as a director to gain an advantage for oneself or someone else, or to cause detriment to the corporation. ${ }^{79}$ In these circumstances a court may make a disqualification order if it is satisfied that the disqualification is justified. ${ }^{80}$ The grounds listed in section 1317E of the Australian Corporations Act are very similar to the grounds of delinquency listed in section 162(5)(c) of the SA Companies Act. In determining whether the disqualification is justified, section $206 \mathrm{C}(2)$ (a) requires a court to have regard to the "person's conduct in relation to the management, business or property" of any corporation. A court may however also take into account any other

76 CDDA, secs 12C(1)(a), 12C(4)(a) and (b) and sched 1.

77 Secretary of State for Trade and Industry $v$ Lubrani (No 2) [1998] BCC 264 at 268; Re Bath Glass Ltd (1998) 4 BCC 130 at 132; Re Migration Services International Ltd [2000] BCC 1095 at 1105. A detailed analysis of the ground of unfitness to be a director under the CDDA is beyond the scope of this article. For further discussion of this topic, see: A Walters "Directors' duties: The impact of the UK Company Directors Disqualification Act 1986" (2000) 21/4 Company Lawyer 110 at 113-19; D Kershaw Company Law in Context (2nd ed, 2012, Oxford University Press) at 807-10; Davies and Worthington Gower Principles, above at note 75 at 241-43; Hannigan Company Law, above at note 75 at 379-83.

79 Australian Corporations Act, secs 1317E, 180(1), 181(1), 182(1) and 183(1).

$80 \mathrm{Id}$, sec $206 \mathrm{C}(1)(\mathrm{b})$. 
issues that it considers appropriate in the circumstances. ${ }^{81}$ Thus this ground for disqualification is more extensive than section 162(5)(c), in that the matters that may be considered by a court are not restricted to the director's conduct in relation to the management of the company. ${ }^{82}$

Under section 206D of the Australian Corporations Act, a court may disqualify a person from managing corporations if, within the last seven years, the person had been an officer of two or more corporations that failed and the court is satisfied that the manner in which the corporation was managed was wholly or partly responsible for the failure and that the disqualification is justified. The circumstances when a corporation will be regarded as having failed relate to its insolvency and winding-up, and to the non-payment of creditors. There is no equivalent provision to section 206D in the SA Companies Act. Conviction for a foreign offence, referenced in section 206EAA(3) of the Australian Corporations Act, is also not listed as a ground for delinquency under the SA Companies Act. ${ }^{83}$

Section 206E of the Australian Corporations Act empowers ASIC to apply to court to disqualify a person from managing corporations if the person has at least twice contravened the act and the court is satisfied that the disqualification is justified. Section 162(5)(e) of the SA Companies Act, which provides that a court must make an order declaring a person to be a delinquent director if the person has at least twice been personally convicted of an offence or subjected to an administrative fine or penalty under any legislation, is akin to section 206E. However, section 206E confines this ground for disqualification to a contravention of the Australian Corporations Act; it does not extend to a contravention of any legislation, as is the case under the more far-reaching section 162(5)(e). "Legislation" is broadly defined in section 162(1) of the SA Companies Act. ${ }^{84}$ This means, for instance, that an organ of state that administers legislation ${ }^{85}$ may institute an application to declare a director delinquent if the director has twice been subject to an administrative fine under that legislation, notwithstanding whether the legislation in question has any connection to the director's position as a director or to his or her functions as a director. It is submitted that this particular ground for judicial disqualification under the SA Companies Act is unnecessarily wide.

81 Id, sec 206C(2)(b).

82 See RP Austin and IM Ramsay Ford, Austin and Ramsay's Principles of Corporations Law (17th ed, 2018, LexisNexis Butterworths) at 277.

83 This provision empowers ASIC to apply to court to disqualify a director who has been disqualified under the law of a foreign jurisdiction. Only New Zealand is currently designated as a prescribed foreign jurisdiction: Corporations Regulations 2001, reg 2D.6.01.

84 For the purposes of sec 162, "legislation" is defined as meaning any national or provincial legislation: "(a) relating to the promotion, formation or management of a juristic person; (b) regulating an industry or sector of an industry; or (c) imposing obligations on, prohibiting any conduct by, or otherwise regulating the activities of, a juristic person".

85 If an organ of state relies on this ground for delinquency, the legislation in question must be administered by that organ of state. 
Under the SA Companies Act, a declaration of delinquency must be made in relation to one of the statutory grounds set out in section $162 .{ }^{86}$ While the MBCA also limits the grounds for the judicial removal of a director to those listed in section 8.09(a) of the MBCA, the corporate legislation of certain US states give courts statutory discretion to rely on grounds for the removal of a director that are not listed in the applicable legislation. For instance, section 1726(c) of the Pennsylvania Business Corporation Law, section 706(d) of the New York Business Corporation Law and section 7-1-2-805 of the Rhode Island Business Corporation Act state that directors may be removed for "cause" by a court, without specifying what that cause may be. A court is given wide discretion to determine whether a particular act of a director constitutes "proper cause". ${ }^{87}$ While the statutory grounds for the judicial disqualification of a director under the CDDA are, as discussed above, a closed list, the factors that a court may take into account in determining the unfitness of a director and in exercising its discretion whether to disqualify a director, are not exhaustive. Likewise, as discussed above, in determining whether a disqualification order is justified under the Australian Corporations Act, a court may have regard to any matters it considers appropriate. It is submitted that, in light of the fact that South African courts do not have discretion whether or not to disqualify a director from holding office, unlike courts in the USA, UK and Australia (as discussed below), it is preferable to have a closed list of grounds on which a director may be declared delinquent.

\section{DURATION OF REMOVAL}

A declaration of delinquency on the ground that a person consented to serve as a director or acted in the capacity of a director while ineligible or disqualified under section 69 of the SA Companies Act, or acted as a director in a manner that contravened a probation order, is unconditional and subsists for that person's lifetime. ${ }^{88}$ On this basis a court is obliged to disqualify a director from office for the duration of his or her lifetime under such circumstances, which, it is submitted, is rather harsh. In all other instances, a declaration of delinquency subsists for seven years from the date of the court order, or such longer period as the court determines at the time of making the declaration,

86 Cook: Geoffrey v Hesber Impala (Pty) Ltd and Others (2014/45832) [2016] ZAGPJHC 23 (19 February 2016), paras 60-61.

87 For a discussion of the meaning of the phrase "for cause", see: Petition of Korff 198 App Div 553 (1921) at 559; Fox $v$ Cody 141 Misc 552, 252 NYS 395 (Sup Ct 1930) at 554; Markovitz $v$ Markovitz 8 A.2d 46 (Pa 1939) at 48; Campbell $v$ Loew's Inc 134 A.2d 852 (1957) at 860-61; DMM Bolling "Removal of directors in closely held corporations" (1959) 12 University of Florida Law Review 234 at 234; KS Ferber Corporation Law (2002, Prentice Hall) at 40-41; and D Cox and TL Hazen Corporations (2nd ed, 2003, Aspen Publishers) at 168.

88 SA Companies Act, sec 162(5)(a), (5)(b) and (6)(a). 
subject to any appropriate conditions. ${ }^{89}$ A South African court has discretion to extend the duration of the delinquency, but has no discretion to determine the minimum period of the delinquency or to reduce the prescribed sevenyear period. In Grancy $v$ Gihwala, ${ }^{90}$ the High Court decided that the purpose of prescribing minimum periods for a delinquency order is to: remove unscrupulous directors from office in order to protect investors; ensure greater consistency in the application of section 162; and ensure that the section has a sufficient deterrent effect. In striking contrast, the CDDA, the Australian Corporations Act, the MBCA and the corporate legislation of relevant US states empower courts to disqualify directors for the period that they consider appropriate.

The disqualification period under the CDDA varies depending on the ground for disqualification. In most instances the CDDA does not prescribe minimum periods of disqualification, as the SA Companies Act does; instead, it prescribes maximum periods. In respect of disqualification for persistent breaches of companies legislation and disqualification on summary conviction, the maximum disqualification is for five years. ${ }^{91}$ However, in other instances, including the disqualification of a director on a finding of unfitness under section 8 of the CDDA, the maximum period of disqualification is 15 years. ${ }^{92}$ It is only with regard to the disqualification of unfit directors of insolvent companies, under section 6 of the CDDA, that both a minimum period of disqualification (two years) and a maximum period of disqualification (15 years) have been prescribed. Courts in the UK are thus given discretion in most instances to determine the minimum period of disqualification. ${ }^{93}$

The Australian Corporations Act confers on courts a high degree of discretion to determine the disqualification period for directors, in that courts are empowered to disqualify directors for the period that they consider appropriate. ${ }^{94}$ It is only with regard to disqualification under section $206 \mathrm{D}$, where the person has been a director of a failed corporation at least twice in seven years, that a maximum period of 20 years is imposed. ${ }^{95}$ Some factors that are considered by Australian courts in exercising their discretion to determine the appropriate disqualification period are: the specific deterrence of the director in question; the general deterrence of the penalty; whether the director has a history of similar breaches; the degree of seriousness of the contraventions;

89 Id, sec 162(6)(b). Some conditions a court may impose are that the director must undertake a designated programme of remedial education (id, sec 162(10)(a)) or be involved in a designated programme of community service (id, sec 162(10)(b)).

90 Above at note 1, para 194.

91 CDDA, secs 3(5) and 5(5).

92 Id, sec 8(4).

93 See Re Sevenoaks Stationers (Retail) Ltd [1991] Ch 164, CA at 174, where the UK Court of Appeal set out useful guidelines to determine the appropriate period of disqualification in instances where the maximum period of disqualification is 15 years.

94 Australian Corporations Act, secs 206C(1), 206E(1) and 206EAA(1).

$95 \mathrm{Id}$, sec $206 \mathrm{D}(1)$. 
whether dishonest conduct is involved (which attracts a longer disqualification period); the remorse shown by the director; the need to balance the personal hardship to the director against the public interest; and the likelihood of the director reforming his or her ways (which is regarded as a mitigating factor). ${ }^{96}$

In a similar vein, section 8.09(a) of the MBCA and the corporate legislation of relevant US states confer discretion on courts to bar the director concerned from re-election for a period prescribed by the court. ${ }^{97}$ Section 10-809(b) of the Arizona Revised Statutes differs from this trend by imposing a maximum period of five years for which a court may bar a director from re-election, but it does not lay down a minimum period in this regard.

Section 162 of the SA Companies Act is patently much stricter than the equivalent legislation in the foreign jurisdictions reviewed here, in that South African courts have no discretion to deviate from the prescribed minimum period of delinquency. The SA Companies Act does, however, offer some relief for directors to apply to court after three years for the suspension of the delinquency order and its substitution with a probation order, and, more than two years thereafter, to have the suspended delinquency order set aside. ${ }^{98}$ The implication of section 162(11) of the SA Companies Act is that the minimum period of a delinquency order, assuming that the application is successful, is effectively three years. Section 162(11) serves to alleviate the severity of a delinquency order. Arguably, that justifies the lack of discretion for a court to determine a minimum period of delinquency. ${ }^{99}$

\section{PRESCRIPTION PERIOD WITH REGARD TO THE JUDICIAL DISQUALIFICATION OF A DIRECTOR}

Under section 162(5)(c) of the SA Companies Act, a court must make an order declaring a person to be a delinquent director if the relevant offence set out in the section was committed by the person "while a director". It is submitted that these words indicate that the application may be brought at any time after the director committed the relevant offence, provided that the offence was committed while the person was a director of the company. The only

96 Re HIH Insurance Ltd (in prov liq); ASIC v Adler [2002] NSWSC 483, para 56; Elliott v Australian Securities and Investments Commission; Plymin $v$ Australian Securities and Investments Commission [2004] VSCA 54 (2004); Rich v ASIC, above at note 17, paras 48-50; ASIC $v$ Axis, above at note 23, paras 8-9.

97 See, for example: California Corporations Code, sec 304; Connecticut General Statutes, sec 33-743(c); District of Columbia Code, sec 29-306.09(c); New York Business Corporation Law, sec 706(d); Pennsylvania Business Corporation Law, sec 1726(c); Rhode Island Business Corporation Act, sec 7-1.2-805(d); and Washington Business Corporation Act, sec 23B.08.090(2).

98 SA Companies Act, sec 162(11) and (12).

99 For a discussion of the application to suspend delinquency orders, see R Cassim "The suspension and setting aside of delinquency and probation orders under the Companies Act 71 of 2008" (2019) 22 Potchefstroom Electronic Law Journal 1. 
time limitation imposed in section 162 is that the person must have been a director of the company within the 24 months immediately preceding the delinquency application. ${ }^{100}$ Apart from this limitation, no prescription period has been imposed with regard to the time period within which a delinquency application must be instituted. ${ }^{101}$

The underlying policy of the legislature with regard to the imposition of a 24 month prescription period is not clear. If a director were to commit an offence set out in section 162(5) and subsequently resign from the company or be removed as a director, he or she would be immune from being declared delinquent if the application were not lodged within 24 months after his or her resignation or removal from the company. A further concern is that the offence committed by the director may be discovered more than 24 months after his or her departure from the company, in which event he or she would be immune from being declared delinquent. This is because the 24 month time period starts to run as soon as the director ceases to be a director of the company, not when the applicant becomes aware of the director's misconduct. ${ }^{102}$ It is not clear why the legislature saw fit to impose a prescription period for an application of delinquency against a former director, but did not impose a prescription period for an application of delinquency against a current director.

In contrast, proceedings under the CDDA for the disqualification of an unfit director of an insolvent company must be commenced within three years of the date on which the company of which that person is or was a director became insolvent. ${ }^{103}$ It is only with the leave of the court that an application for the disqualification of an unfit director of an insolvent company may be made more than three years after the company becomes insolvent. ${ }^{104}$ In Secretary of State for Trade and Industry $v$ Davies and Others, ${ }^{105}$ the UK Court of Appeal stated that being a director represents a person's means of livelihood and his ability to carry on his business activities, and, if he has to defend proceedings that may disqualify him from being a director, he should know

100 SA Companies Act, sec 162(2), (3) and (4). See further Companies and Intellectual Property Commission v Zwane (73548/2018) [2019] ZAGPPHC 381 (8 August 2019), para 24.

101 It is arguable that the Prescription Act 68 of 1969, which deals with the effect of the effluxion of time on obligations, would not apply in this instance because it applies primarily to the acquisition of ownership by prescription, the acquisition and extinction of servitudes by prescription and the prescription of debts, while sec 162 of the SA Companies Act relates to a declaration that affects a person's status.

102 By way of comparison, prescription on a debt begins to run as soon as the debt is due, but the debt is not regarded as being due until the creditor has knowledge of the identity of the debtor and the facts from which the debt arises: Prescription Act 68 of 1969 , sec 12(3). See further R Cassim "Delinquent directors under the Companies Act 71 of 2008: Gihwala v Grancy Property Limited 2016 ZASCA 35" (2016) 19 Potchefstroom Electronic Law Journal 1 at 15 .

103 CDDA, sec 7(2).

104 Ibid.

105 [1996] 4 All ER 289 at 302. 
about this within a reasonable time instead of being left in a state of uncertainty. The requirement to proceed timeously against miscreant directors is imposed both to protect directors so that they may be able to organize their affairs once the statutory time limit has passed free from the risk of future disqualification, ${ }^{106}$ and to protect the public because it is "obviously wrong" in the public interest that a person who is unfit to be a director should be left free to be a director for any longer than is necessary. ${ }^{107}$ In considering whether to grant leave to commence disqualification proceedings after the statutory period had passed, a court must take into account the length of the delay, the reasons for the delay, the strength of the case against the director and the degree of prejudice caused to the director by the delay. ${ }^{108}$ In Secretary of State $v$ Davies, ${ }^{109}$ the UK Court of Appeal stated that the power to extend the statutory period to apply for disqualification proceedings against directors must be exercised sparingly and with great caution.

For the reasons propounded by the UK Court of Appeal, as discussed above, it is submitted that a statutory time limit of three years should be imposed with regard to delinquency applications under the SA Companies Act. It is further submitted that the 24-month prescription period imposed for a director who ceases to be a director of the company should be extended to three years. In order to ensure that, in those instances where an application to declare a director delinquent cannot be lodged within the three-year time period, it is submitted that (as is the case under section 7(2) of the CDDA), an application to declare a director delinquent after the three-year period should be possible with the leave of the court. This would ensure that delinquent directors are not immune from applications to declare them delinquent after three years, but leave of the court should be sought to bring such an application after three years. This would serve to balance the public interest with the director's legitimate interests. It is submitted that this would further be in accord with the purposes of the SA Companies Act enshrined in sections $7(\mathrm{j})$ and $7(\mathrm{l})$ respectively, of encouraging the efficient and responsible management of companies, and of providing a predictable and effective environment for the efficient regulation of companies.

\section{DISCRETION OF THE COURT TO DISQUALIFY A DIRECTOR FROM HOLDING OFFICE}

If any of the grounds set out in section 162 of the SA Companies Act are satisfied, a court is obliged to make an order declaring a person to be a delinquent

106 Id at 297.

107 Ibid.

108 Re Probe Data Systems Ltd (No 3), Secretary of State for Trade and Industry $v$ Desai [1992] BCC 110 at 118; Re Polly Peck International plc (In Administration) (No 3), Secretary of State for Trade and Industry $v$ Ellis [1993] BCC 890 at 893-94; Secretary of State $v$ Davies, above at note 105 at 296.

109 Id at 298. 
director, thereby disqualifying him or her from office. A South African court has no discretion in this regard. ${ }^{110}$ In sharp contrast, under the CDDA, ${ }^{111}$ the Australian Corporations Act, ${ }^{112}$ the $\mathrm{MBCA}^{113}$ and the corporate legislation of the US states ${ }^{114}$ that permit the judicial removal of directors, courts have discretion whether or not to disqualify a director from holding office. In this regard, section 162(5) of the SA Companies Act is stricter than the equivalent provisions in the foreign jurisdictions reviewed here.

It may be argued that South African courts were denied this discretion in the light of the seriousness of the offences listed in section 162(5). The lack of discretion may arguably serve to promote consistency and certainty with regard to declaring directors delinquent. ${ }^{115}$ Nevertheless, the absence of discretion has the effect that South African courts may not consider mitigating factors in declaring directors delinquent. For instance, the courts are not empowered to consider the remorse shown by the director, the need to balance the personal hardship to the director against the public interest, the potential of the director to reform, or the likelihood of the director refraining from any future misconduct in exercising his or her functions and duties.

\section{INTERFERENCE BY THE JUDICIARY IN THE COMPANY'S INTERNAL AFFAIRS}

While the judicial disqualification of directors is important and appropriate in certain instances (such as when the shareholders or the board of directors are unable to remove a director from office), in disqualifying directors from holding office, the courts are in effect disregarding the results of the election process by which the directors were elected by the shareholders or appointed by the directors. Such action intrudes on the prerogative of shareholders to elect directors and on the prerogative of the board to appoint directors to office. The disqualification of directors by the judiciary thus impacts on the

110 This is made clear by the word "must" in sec 162(5). It should, however, be noted that, with regard to the ground for delinquency in sec 162(5)(f) of the SA Companies Act (director of a company that is convicted of an offence within a period of five years), which may only be raised by an organ of state, a court has discretion to grant a declaration of delinquency since the order will only be granted if "the court is satisfied that the declaration of delinquency is justified".

111 CDDA, secs 2, 3, 4, 5, 5A, 8 and 10. The only two instances when a disqualification order is mandatory under the CDDA are under sec 6 relating to the disqualification of unfit directors of insolvent companies and sec 9A relating to a competition disqualification order.

112 See for instance sec $206 C(1)(b)$.

113 MBCA, sec 8.09(a).

114 Refer for example to: DGCL, sec 225(c); California Corporations Code, sec 304; Connecticut General Statutes, sec 33-743(a); Pennsylvania Business Corporation Law, sec 1726(c); and Washington Business Corporation Act, sec 23B.08.090(1).

115 See S Griffin "The disqualification of unfit directors and the protection of the public interest" (2002) 53/3 Northern Ireland Legal Quarterly 207 at 210. 
internal structure of the company and alters the composition of the body elected by the board or by the shareholders to represent their interests. ${ }^{116}$

As a general principle, the courts are disinclined to interfere in the internal operations of a company involving management decisions. ${ }^{117}$ The courts have adopted the policy that they should not be involved in situations where the parties are capable of resolving their disputes internally. ${ }^{118}$ The election, retention, dismissal or removal of officers, directors and employees are examples of such internal corporate operations, which essentially involve management decisions. ${ }^{119}$ However, section 162 of the SA Companies Act does not contain provisions designed to minimize judicial interference in the company's internal affairs.

In contrast, the MBCA is designed to interfere as little as possible with the company's internal affairs. For instance, under section 8.09(a) of the MBCA, not only has a court been given discretion to remove a director from office based on a contravention of the grounds listed in that provision (which are similar to the grounds set out in section 162(5)(c) of the SA Companies Act), but it may do so only if, considering the director's course of conduct and the inadequacy of other available remedies, removal would be in the corporation's best interests. It is noteworthy that section 8.09(a) of the MBCA states that a court may remove a director from office or "may order other relief". Several US states permit a court to order other relief instead of removing a director from office. ${ }^{120}$ Section 225(c) of the DGCL goes further in providing that a court may remove a director from office if judicial removal is necessary to avoid irreparable harm to the corporation. The corporate legislation of some US states provides that a court may remove a director from office only if removal is in the best interests of the corporation. ${ }^{121}$ These provisions

116 ON Sirodoeva-Paxson "Judicial removal of directors: Denial of directors' license to steal shareholders' freedom to vote" (1999) 50 Hastings Law Journal 1 at 6.

117 Maynard v Office Appliances (SA) (Pty) Ltd 1927 WLD 290 at 293; Kronenberg $v$ Sullivan County Steam Laundry Co 91 NYS 2d 144 (1949), para 8; Yende v Orlando Coal Distributors (Pty) Ltd and Others 1961 (3) SA 314 (W); Breetveldt and Others $v$ Van Zyl and Others 1972 (1) SA 304 (T); Wilkes $v$ Springside Nursing Home, Inc Mass $353 \mathrm{NE} 2 \mathrm{~d} 657$ (1976) at 662; Connolly v Bain 484 NW 2d 207 (Iowa App 1992) at 211; Demoulas $v$ Demoulas 1996 WL 511519 (Mass Super Ct Pct 1, 1996), para 32; Mbethe $v$ United Manganese of Kalahari (Pty) Ltd 2016 (5) SA 414 (GJ), para 59; CDH Invest NV v Petrotank South Africa (Pty) Ltd and Another 2018 (3) SA 157 (GJ), para 81.

$118 \mathrm{CDH}$ Invest $v$ Petrotank, id, para 80.

119 Wilkes $v$ Springside, above at note 117 at 662; Connolly $v$ Bain, above at note 117 at 211; Demoulas $v$ Demoulas, above at note 117 , para 32.

120 See for example: Connecticut General Statutes, sec 33-743(a) and (d); District of Columbia Code, sec 29-306.09(a)(2) and (d); and South Dakota Business Corporation Act, sec 47-1A-809.

121 See for example: Arizona Revised Statutes, sec 10-809(A)(2); Michigan Business Corporation Act, sec 450.1514(1); South Carolina Code of Laws, sec 33-8-109(a); and Washington Business Corporation Act, sec 23B.08.090(1). 
ensure that a court does not interfere unduly with a company's internal affairs.

In contrast, under section 162 of the SA Companies Act, a court is not required to consider whether any other remedies are adequate before declaring a director delinquent and hence disqualifying him or her from office. The judicial disqualification of a director is not a remedy of last resort. A court is also not required to consider whether declaring a director delinquent is in the company's best interests. Furthermore, a court is not given discretion to grant other relief, save for making the declaration of delinquency subject to conditions that it considers appropriate. ${ }^{122}$ From this it is clear that the SA Companies Act adopts a stricter approach than the equivalent provisions in the foreign jurisdictions considered above that have influenced it.

In Gihwala $v$ Grancy, ${ }^{123}$ the Supreme Court of Appeal stated that the fact that foreign legislation gives courts wider discretion to disqualify directors from office does not render section 162(5)(c) of the SA Companies Act constitutionally problematic, and that the provision nonetheless remains rational. It would have been instructive if the court had, in ascertaining the rationality of section 162(5)(c), considered the equivalent provisions of the foreign jurisdictions discussed above. It is submitted that the approach adopted to the removal of a director under section 8.09 of the MBCA, the equivalent provisions under the DGCL and the corporate legislation of the US states that permit the judicial removal of a director, is commendable and has the effect of limiting the extent of judicial interference in a company's internal affairs.

\section{CONCLUSION}

Important lessons are to be gleaned from certain leading foreign jurisdictions so as to ensure that the South African provisions on the judicial disqualification of directors do not go too far in certain respects and that a proper balance is maintained. As reinforced by section 5(2) of the SA Companies Act, it is submitted that shareholders should be permitted to institute delinquency proceedings by means of a derivative action, as this would have the advantage of curbing abuse of section 162 of the SA Companies Act. A three-year statutory time limit for applications to declare a director delinquent should be imposed by section 162, and provision should be made for an application, with the leave of the court, to be lodged to declare a director delinquent after the three-year period has expired. South African courts should be given discretion as to whether to declare directors delinquent. Moreover, they should be required to consider whether the declaration of delinquency and the consequent disqualification of the director would be in the company's best interests. In addition, they should have the power to consider the adequacy of any remedies other than a declaration of delinquency.

122 SA Companies Act, sec 162(6).

123 Above at note 16, para 145. 
While the core of the regime set out in section 162 of the SA Companies Act is to hold directors accountable, section $7(\mathrm{i})$ of the act at the same time requires a balance to be maintained between the rights and obligations of shareholders and directors within companies. It is submitted that the recommendations above would do much to maintain this balance and would moreover promote the development of the South African economy by encouraging entrepreneurship and enterprise efficiency, encouraging the efficient and responsible management of companies, and providing a predictable and effective environment for the efficient regulation of companies, as required by section 7 of the SA Companies Act. Declaring a director delinquent is a severe remedy, with a penal element and harsh consequences. It must not be applied without due and proper consideration by a court. As the UK Court of Appeal emphasized in Secretary of State $v$ Davies, ${ }^{124}$ to be a director of a company is a privilege, but it is not one of which a person should be unjustly deprived.

\section{CONFLICTS OF INTEREST}

None 